\title{
Pengelolaan kecemasan dan ketidakpastian dalam komunikasi mahasiswa di kampus IAIN Pontianak
}

\author{
Ibrahim \\ IAIN Pontianak, Kalimantan Barat, Indonesia
}

\begin{abstract}
ABSTRAK
Berada dalam situasi yang baru, berasal dari latar belakang kebudayaan yang berbeda, dan dihadapkan pada satu pengalaman dan harapan tertentu, seringkali memunculkan rasa cemas (kecemasan) dan tidak menentu (ketidak-pastian) dalam komunikasi. Akibatnya pun, seringkali proses komunikasi dan pemaknaan pesan yang mindfulness sulit didapatkan secara maksimal. Karena itu penelitian ini bertujuan untuk mengetahui bagaimana pengelolaan kecemasan dan ketidak-pastian dalam komunikasi antar mahasiswa Jurusan KPI IAIN Pontianak, terkait dengan proses dan pemaknaan pesan yang mindfulness antarbudaya. Dengan pendekatan kualitatif dan metode deskriptif, peneliti menggunakan lembar korespondensi sebagai teknik utama pengumpulan datanya, didukung dengan FGD dan observasi terhadap proses interaksi antar mahasiswa dalam perkuliahan di kelas. Hasil penelitian ini mendapati bahwa proses komunikasi dan pemaknaan pesan yang mindfulness berdasarkan konsep pengelolaan kecemasan dan ketidakpastian antarbudaya berlaku dalam pengalaman komunikasi mahasiswa IAIN Pontianak. Secara spesifik, kajian ini menemukan; 1) kecemasan dan ketidak-pastian terjadi dalam proses komunikasi dan pemaknaan pesan pada awal-awal pertemuan kelas; 2) proses komunikasi dan pemaknaan pesan dalam situasi cemas dan tidak-pasti berlangsung dalam tahapantahapan tertentu; 3) pengelolaan kecemasan dan ketidak-pastian dalam komunikasi mahasiswa dijalankan dalam bentuk penerimaan dan adaptasi, atau penolakan dan menghindari; 4) proses pemaknaan pesan yang mindfulness antarbudaya berlangsung dalam berbagai varian, bahkan sangat beragam mengikuti pengalaman budaya yang berbeda.
\end{abstract}

Kata-kata Kunci: Kecemasan-ketidakpastian; proses komunikasi; pemaknaan pesan; mindfulness; komunikasi antarbudaya

\section{Management of anxiety and uncertainty communication in IAIN Pontianak}

\section{ABSTRACT}

Being in a new situation, coming from a different cultural background, and faced with a particular experience and certain hope, it often raises anxiety and uncertainty in communication. As a result, the process of communication and meaningful messages are often difficult to obtain optimally. Therefore this study aims to reveal how the management of anxiety and uncertainty in the communication of KPI Department students at the IAIN Pontianak related to the process and meaning of messages that are intercultural mindfulness. By using qualitative approaches and descriptive methods, researchers used correspondence sheets as the main technique of data collection, supported by Forum Group Discussion and observation of the interaction process among students in lecturing in the classroom. The results of this research found that the process of communication and meaningful messages based on the concept of managing intercultural anxiety and uncertainty prevailed in the communication experienced of IAIN Pontianak students. The specific of finding study; 1) anxiety and uncertainty occur in the process of communication and meaning of messages at the beginning of class meetings; 2) the process of communication and the meaning of the message in an anxious and uncertain situation takes place in certain stages; 3) management of anxiety and uncertainty in student communication is carried out in acceptance and adaptation, or rejection and avoidance; 4) the process of interpreting the message that intercultural mindfulness takes place in various variants, even very diverse following different cultural experiences.

Keywords: Anxiety-uncertainty; communication process; message meaning; mindfulness; intercultural communication

Korespondensi: Ibrahim. IAIN Pontianak, Jl. Letjend Suprapto, Benua Melayu Darat, Kec. Pontianak Sel., Kota Pontianak, Kalimantan Barat 78113.Email: ab_irhamiy@yahoo.com 


\section{PENDAHULUAN}

Sebagai masyarakat bangsa yang pluralis, nyaris tidak ada satu pun wilayah yang sama sekali didiami oleh masyarakat yang homogen. Persoalannya hanyalah besaran persentase sebuah masyarakat dan keragamannya. Artinya bahwa, masyarakat bangsa ini memang sudah ditakdirkan untuk hidup bersama dan berdampingan dengan segala perbedaan di dalamnya, baik etnik, agama, bahasa, adat istiadat, budaya dan sebagainya.

Dalam prakteknya, keragaman ini seringkali menjadi kendala dalam proses komunikasi dan hubungan sosial. Seringkali keragamaan menjadi "terdakwa" atas terjadinya persoalan dan konflik sosial. Karena faktanya setiap orang akan mengalami tantangan dan problem tersendiri dalam membangun komunikasi dalam lingkup partisipan yang beragam itu.

Diantara tantangan dan problem komunikasi dalam situasi yang baru (individu dalam suatu kelompok baru) adalah perasaan cemas ata kecemasan (Anxeity) dan kebimbangan atau ketidakpastian (Uncertainty), baik dalam berprilaku maupun dalam memahami pesanpesan komunikasinya.

Secara bahasa Anxiety dimaknai sebagai kecemasan, atau perasaan cemas dan tidak menentu, dan merupakan gejala psikologis (reaksi alamiah) yang bisa terjadi pada semua orang (Ramaiah, 2003). American Psichiatric Association mendefenisikan anxiety sebagai kecemasan atau ketegangan, perasaan tidak nyaman yang disebabkan adanya sesuatu yang dianggap membahayakan, meskipun terkadang sumber bahaya tersebut tidak jelas. Atau suatu keadaan tertekan yang tidak menyenangkan dan mengindikasikan keberadaan sesuatu yang berbahaya (Edelmann, 1992).

Kecemasan juga dapat dipahami sebagai satu situasi emosi yang tidak menyenangkan, yang ditandai dengan istilah-istilah seperti "kekhawatiran", "keprihatinan", dan "rasa takut". Kecemasan seperti itu kadang-kadang kita alami dalam tingkat yang berbeda-beda (Handini, 2014).

Kecemasan tidak sama dengan ketakutan (fear). Jika ketakutan merupakan reaksi individu terhadap sejumlah faktor yang mengancam keselamatan, maka kecemasan (anxiety) merupakan keadaan dimana individu tidak mampu bereaksi dan kehilangan kemampuan untuk melawan atau lari dari situasi yang mengancam. Individu yang mengalami kecemasan (anxiety) merasa ragu bahwa tindakan yang akan dilakukan berhasil atau tepat (Handini, 2014).

Gudykunst, seorang profesor yang mengembangkan teori Managemen Kecemasan dan Ketidakpastian dari (Berger, Charles R., Roloff, Michael E., \& Roskos-Eweldsen, 2014) menjelaskan lebih lanjut dengan mengacu pada istilah "orang asing", yakni mereka yang tidak kenal dengan lingkungan sekitar, dan karenanya interaksi tersebut ditandai dengan kecemasan dan ketidakpastian (Diana, Afriyanti \& Lukman, 2018). Dengan kata lain, Gudykunst menggambarkan anxiety dan uncertainty sebagai situasi dan kondisi seseorang yang merasa asing (terasing), tidak nyaman dan kebingungan ketika berada dalam suasana pertemuan yang baru antarbudaya (Sukmono \& Junaedi, 2014)

Anxiety atau perasaan tidak nyaman, khawatir, gelisah, dan takut akan membawa pelakunya pada sikap yang tidak pasti atau ketidakpastian (uncertainty). Dalam banyak kasus komunikasi, ketidakpastian ini akan melahirkan pesan-pesan yang tak pasti (ambiguity) sebagaimana kajian Oluga mengenai Ambuitas dalam komunikasi manusia; sebab, akibat dan penanganannya (Oluga, 2010). Kajian lain melaporkan bahwa situasi kecemasan dan ketidakpastian juga terjadi dalam komunikasi antarbudaya antara auditor dan auditee dalam pelaksanaan fungsi dan tugas pemeriksaan (Diana, Afriyanti \& Lukman, 2018).

Dengan kata lain, ketidakpastian (uncertainty) seringkali bersumber dari perasaan yang tidak menentu, cemas, takut dan khawatir. Kecemasan dan ketidakpastian merupakan sikap psikologis yang secara bersamaan mempengaruhi perilaku komunikasi seseorang.

Lantas, apa sebenarnya yang memicu terjadinya kecemasan dan ketidakpastian dalam komunikasi Menurut Beck, Amery \& Greenberg sebagaimana dikutif Wolman \& Stricker (Handini, 2014) terdapat lima faktor yang memicu terjadinya kecemasan dalam diri seseorang (anxiety): a) Genetic Inheritability, yakni faktor pewarisan genetis dalam bentuk respon sarap otonom dalam menerima rangsangan; b) Phycical Diseases State, 
yakni kecemasan (anxiety) yang lebih banyak disebabkan oleh faktor penyakit fisik, dimana seorang individu merasa khawatir akan kondisi, ketidakmampuan diri dan segala macam kelemahan sendiri; c) Phychological Trauma, yakni ketakutan mental ketika dihadapkan dengan situasi yang serupa dengan pengalaman terdahulu yang menimbulkan trauma; d) Absence of Coping Mechanisme,yakni sebuah situasi dimana individu yang mengalami kecemasan seringkali menunjukkan defisit dalam merespon atau menghadapi kecemasan itu sendiri, merasa tidak berdaya untuk menemukan cara atau strategy mengatasi masalah yang dihadapi tersebut; e) Irrational Thougt, Assumptions and Cognitive Processing Errors, yakni adanya pikiran-pikiran yang irrasional, atau proses yang keliru dalam memberikan asumsi-asumsi tentang suatu keadaan atau peristiwa yang dihadapi.

Faktor lain yang bisa menimbulkan kecemasan dalam komunikasi adalah selfefficacy, suatu keyakinan individu bahwa dirinya mampu melakukan sesuatu dalam situasi tertentu dengan berhasil. Melalui penelitiannya terhadap mahasiswa di kampus IAIN Sunan Ampel, Wahyuni menyimpulkan bahwa, semakin baik self-Efficacy semakin berkurang tingkat kecemasan, semakin terampil individu dalam berkomunikasi maka semakin rendah tingkat kecemasan dalam komunikasi (Wahyuni, 2015).

Kecemasan dan ketidakpastian juga bisa terjadi dalam perjumpaan dua kelompok partisipan yang berasal dari latar belakang sosiobudaya yang berbeda. Ahmad dan kolega melaporkan situasi kecemasan dan ketidakpastian yang berlaku selama proses adaptasi budaya dalam komunikasi para pelajar Melayu Malaysia yang kuliah di Australia dan Inggris (Ahmad et al., 2015)

Keterampilan komunikasi individu sangat erat kaitannya dengan kemampuan seseorang dalam merefresentasikan diri dan identitas budayanya dalam ruang komunikasi. Sebab pada dasarnya ruang keseharian merupakan refresentasi identitas diri pribadi (Saputra, 2017)

Kecemasan dan ketidakpastian dalam komunikasi pada prakteknya juga bisa dipengaruhi oleh perbedaan dalam kode verbal dan nonverbal. Dengan situasi ini, seringkali interaksi antarbudaya mengalami kegagalan atau miscommunication (Kelly, 2014).

Perasaan cemas atau kecemasan dibiarkan berlangsung lama dan tampa penanggulangan yang baik dan tepat bisa menjadi masalah dalam komunikasi. Karena itu, menurut (Handini, 2014) ada dua strategi penanggulangan masalah kecemasan: Pertama, menitikberatkan masalah. Artinya, individu akan menilai situasi yang menimbulkan kecemasan dan kemudian melakukan sesuatu untuk mengubah atau menghindarinya; kedua, menitikberatkan emosi. Artinya, individu berusaha mereduksi perasaan cemas melalui berbagai macam cara dan tidak secara langsung menghadapi masalah yang menimbulkan kecemasan itu.

Dalam konteks kajian ini, kecemasan (anxiety) dipahami sebagai perasaan cemas yang berwujud rasa tak menentu, ragu-ragu, khawatir, bimbang, dan serba tidak jelas (ketidak-pastian) disebabkan faktor-faktor tertentu, baik internal maupun eksternal yang mempengaruhi pilihan sikap dan cara berkomunikasi yang baik dan berhasil dalam konteks antarbudaya. Dengan kata lain, ketidakpastian lebih merupakan akibat lanjutan dari kecemasan, yang dalam konteks kajian ini lebih disebabkan faktor situasi dan kondisi yang asing, baru, aneh dan tidak biasa bagi partisipan.

Perbedaan latar belakang budaya seringkali menjadi pertimbangan akankah perilaku tertentu cocok dan sesuai untuk situasi baru yang sedang dihadapi? Atau, akankah sebuah simbol yang diterima dalam lingkungan partisipan yang baru memiliki makna (pesan) yang sama dengan apa yang dipahami dalam pengalaman budaya asal. Akibatnya, memunculkan perilaku (pesan) yang ambigu, bahkan tidak pasti antarbudaya.

Kaitannya dengan perbedaan latar belakang dalam komunikasi antarbudaya, menarik untuk menyimak pernyataan berikut; bahwa budaya dengan segala nilainya itulah yang mengajarkan kita tentang "apa yang boleh dan tidak boleh dibincangkan", "apa dan bagaimana cara yang baik dalam membincangkan". Budaya dengan segala nilainya menjadi acuan untuk menyatakan bahwa kejujuran itu benar-benar lebih baik daripada ketidak-jujuran dalam komunikasi.." (Ibrahim, 2017).

Seorang imigran yang baru masuk dalam wilayah komunitas budaya yang baru, pastinya mengalami situasi cemas, tidak-pasti, yang karenanya diperlukan waktu untuk melakukan penyesuaian dan adaptasi. Situasi awal 
yang diliputi dengan perasaan tak menentu dan membingungkan inilah yang disebut dengan kecemasan dan ketidakpastian dalam komunikasi antarbudaya.

Seorang mahasiswa baru yang belum mengenal teman-temannya, juga mengalami situasi cemas dan ketidakpastian ketika pertama kali bertemu di kelas. Karena mereka tidak saling kenal satu sama lain, berasal dari daerah dan latar belakang yang juga berbeda menjadikan situasi komunikasi berlangsung dengan kaku, grogi dan penuh ketidakpastian. Kondisi ini akan sangat menentukan dalam proses komunikasi dan pemaknaan pesan yang benar dan tepat dalam komunikasi antarbudaya.

Contoh di atas memberikan indikasi bahwa situasi ini mungkin saja terjadi pada setiap kita dalam konteks masyarakat plural (majemuk) ini. Oleh karena itu, kita perlu mengelola situasi ini dengan baik, sehingga tidak menjadi kendala yang berkepanjangan dalam membangun komunikasi yang baik dan berhasil (mindfulness) antarbudaya. Untuk mengatasi persoalan tersebut, seorang Gurubesar di Universitas California, memperkenalkan sebuah teori pengelolaan kecemasan dan ketidak-pastian yang disebut teori AUM (Anxeity-Uncertainty Management).

Gudykunst mengembangkan teori ini ketika menangani tentang komunikasi antarbudaya bagi angkatan laut Amerika Serikat yang berada di Jepang pasca perang dunia II, ketika ia bekerja untuk membantu tentara Amerika Serikat di Jepang beserta keluarganya untuk melakukan adaptasi dengan lingkungan budaya di Jepang yang aneh bagi orang Amerika Serikat (Sukmono \& Junaedi, 2014)

Anxiety-Uncertainty Management (AUM) sendiri bermakna sebagai teori pengelolaan kecemasan (anxiety) dan ketidakpastian (uncertainty). Teori ini mempercayai bahwa kemampuan dalam mengelola kendala-kendala komunikasi akan memberikan motivasi kepada setiap orang melakukan komunikasi antarbudaya yang efektif (Raharjo, 2004).

Teori AUM ini memfokuskan kajian pada pertemuan kultural antara in-groups (dalam kelompok besar) dengan strangers (orang-orang yang baru-terasing dari kelompok). Ketika seseorang yang baru dan merasa terasing dengan kelompok baru yang dihadapinya, seringkali komunikasinya diliputi oleh rasa kecemasan dan ketidakpastian dalam bertindak (Sukmono \&
Junaedi, 2014). Dalam konteks yang demikian, kedua belah pihak mesti dapat secara akurat memprediksikan dan menjelaskan perilaku masing-masing untuk mencapai komunikasi yang efektif (effective communication).

Pentingnya pengelolaan kecemasan dan ketidakpastian tersebut guna mewujudkan proses komunikasi dan pemaknaan pesan yang mindfulness antar budaya bisa ditemukan dalam banyak ranah komunikasi. Ramlani Lina Sinaulan mengkaji secara khusus komunikasi layanan kesehatan antara pasien dengan perawat, dan perawat sesama perawat. Kajian tersebut menunjukkan bahwa kemampuan membangun komunikasi terapeutik sangat menentukan efektifitas komunikasi layanan kesehatan, dalam hal ini membantu proses penyembuhan pasien di rumah sakit (Sinaulan, 2016).

Mindfulness merupakan aspek penting dalam diskusi anxiety dan uncertainty. Dalam konsep ini, mindfulness dipahami sebagai satu komunikasi yang dilakukan guna mengurangi perasaan cemas (anxiety) dan tidakpasti (uncertainty). Dalam prakteknya, konsep ini dilakukan dengan cara memperhatikan ketika orang lain berbicara dan mencari tahu bagaimana menanggapi orang lain tersebut berbicara (Sukmono \& Junaedi, 2014). Mindfulness dapat dipahami sebagai kemampuan untuk hidup dengan penuh kesadaran diri (Wesmira, 2016). Dalam konteks komunikasi dan hubungan antarbudaya, mindfulness berarti kemampuan untuk hidup dan membangun relasi dan interaksi dengan penuh kesadaran diri antarbudaya (Littlejohn \& Foss, 2009).

Untuk mewujudkan mindfulness dalam komunikasi antarbudaya, (Raharjo, 2004) menuliskan beberapa situasi dan kondisi komunikasi berikut:

Pertama, mesti adanya kompetensi yang tinggi pada individu antarbudaya berupa kemampuan mengintegrasikan komponen motivasi, pengetahuan, dan kecakapan sehingga bisa berkomunikasi secara layak dan memuaskan.

Kedua, lingkungan pemukiman individu antarbudaya juga tidak boleh tersegregasi (terisolasi) secara sosial, sehingga memberikan kontribusi bagi terciptanya situasi komunikasi yang baik dan berhasil.

Ketiga, penciptaan ruang sosial (social space) berupa "wilayah" yang memungkinkan 
mereka bertemu, berkomunikasi, dan saling mempengaruhi sangat menentukan proses komunikasi yang berhasil (mindful).

Sementara menurut (Wesmira, 2016), ada tujuh hal yang penting diperhatikan sebagai upaya meningkatkan kualitas hidup dengan kesadaran diri yang maksimal (mindful), yakni: 1) berilah perhatian penuh terhadap apa yang sedang di hadapi. Jangan terlalu memikirkan masa lalu, apalagi khawatir akan masa depan; 2) nikmati apapun yang anda miliki saat ini; 3) terbukalah untuk setiap perasaan dan pengalaman, termasuk tahapan dan perubahan yang harus anda lalui dalam hidup; 4) jangan mudah memberi penilaian, sebaliknya tempat segala sesuatu itu seperti apa adanya;5) terimalah segala sesuatu dengan lapang dada, berusahalah untuk lebih toleran terhadap apapun yang datang, dan perluas penerimaan ini kepada orang lain; 6) bersyukurlah dengan apa yang anda hadapi, meresapi keindahan, dan apa yang alam berikan pada anda. Sadari bahwa semua makhluk ingin bahagia, aman dan menghindari penderitaan; 7) bersikap fleksibel terhadap orang dan pengalaman. Sadari bahwa hidup selalu berubah.

Dengan demikian dapat dipahami bahwa mindfulness dalam komunikasi antarbudaya membawa pada pengertian komunikasi yang baik dan berhasil, baik dalam proses maupun pemaknaan pesan. Dalam situasi multikultural, keberhasilan komunikasi antarbudaya juga ditentukan oleh kemampuan menyesuaikan diri, sikap dan identitas budaya dalam komunikasi. Dalib dan kolega melakukanpenelitian terhadap proses komunikasi antar mahasiswa yang berbeda budaya di kampus Malaysia menyimpulkan bahwa, kompetensi antarbudaya ditandai oleh adanya sikap yang dinamis dan terbuka dalam bentuk penyesuaian diri, perubahan sikap dan identitas kebudayaan dalam berkomunikasi (Dalib, Harun \& Yusof, 2017).

Kecemasan dan ketidakpastian merupakan situasi yang kerap dialami oleh partisipan komunikasi yang berasal dari latar belakang sosial budaya yang berbeda. Karena itu, ia situasi ini perlu dikelola dengan baik dan tepat, mulai dari proses komunikasinya, proses pemaknaan pesan, hingga kemungkinan mencapai komunikasi yang efektif(mindfulness) antarbudaya. Karena itu, artikel ini mengambil fokus mengenai pengelolaan kecemasan dan ketidakpastian dalam Komunikasi Antarbudaya pada Mahasiswa IAIN Pontianak angkatan 2014/2015. Dari fokus tersebut, secara spesifik artikel ini bertujuan untuk mendiskusikan empat hal: Proses Komunikasi Antarbudaya pada mahasiswa; proses pemaknaan pesan dalam komunikasi yang mereka lakukan; pengelolaan kecemasan dan ketidakpastian dalam komunikasi; dan proses pemaknaan pesan yang mindfulness dalam komunikasi antarmahasiswa.

\section{METODE PENELITIAN}

Artikel ini diolah dari hasil penelitian yang dilakukan kepada mahasiswa IAIN Pontianak angkatan 2014/2015, Jurusan Komunikasi Penyiaran Islam yang terdiri dari 2 kelas (A \& B). Kelas A terdiri dari 15 orang mahasiswa yang berasal dari latar belakang budaya, suku, gender dan asal daerah yang berbeda. Begitupun dengan kelas B yang terdiri dari 19 orang mahasiswa yang juga berasal dari latar belakang sosial budaya, suku, gender dan asal daerah yang saling berbeda.

Dengan pendekatan kualitatif dan metode deskripif, penelitian ini dilakukan untuk mengungkap persoalan pengelolaan kecemasan dan ketidak-pastian dalam komunikasi antarmahasiswa, terutama untuk interaksi awal dalam proses memaknai pesan yang mindfulness antarbudaya. Mahasiswa dipilih sebagai objek dalam kajian ini sesuai dengan konteks komunikasi antarbudaya, dimana sebuah komunikasi berlangsung melibatkan partisipan dari latar belakang budaya.

Dari sisi etnik, mahasiswa IAIN Pontianak terdiri dari Melayu, Madura, Sunda, Jawa, dan Bugis. Dari sisi asal daerah, mahasiswa IAIN berasal dari berbagai daerah di Kalimantan Barat seperti Ketapang, Sambas, Mempawah, Kapuas Hulu, Sintang, dan bahkan dari luar Kalimantan Barat. Karena itu, sangat layak interaksi di kelas ditempatkan sebagai ranah komunikasi Antarbudaya dalam kajian ini.

Teknik pengumpulan data yang digunakan dalampenelitianiniadalah observasi, wawancara tak langsung melalui lembaran korespondensi, dan Focus Group Discussion (FGD). Observasi dilakukan untuk melihat proses komunikasi yang berlangsung antar mahasiswa yang berasal dari latar belakang budaya yang berbeda, baik dalam proses pertemanan maupun dalam proses 


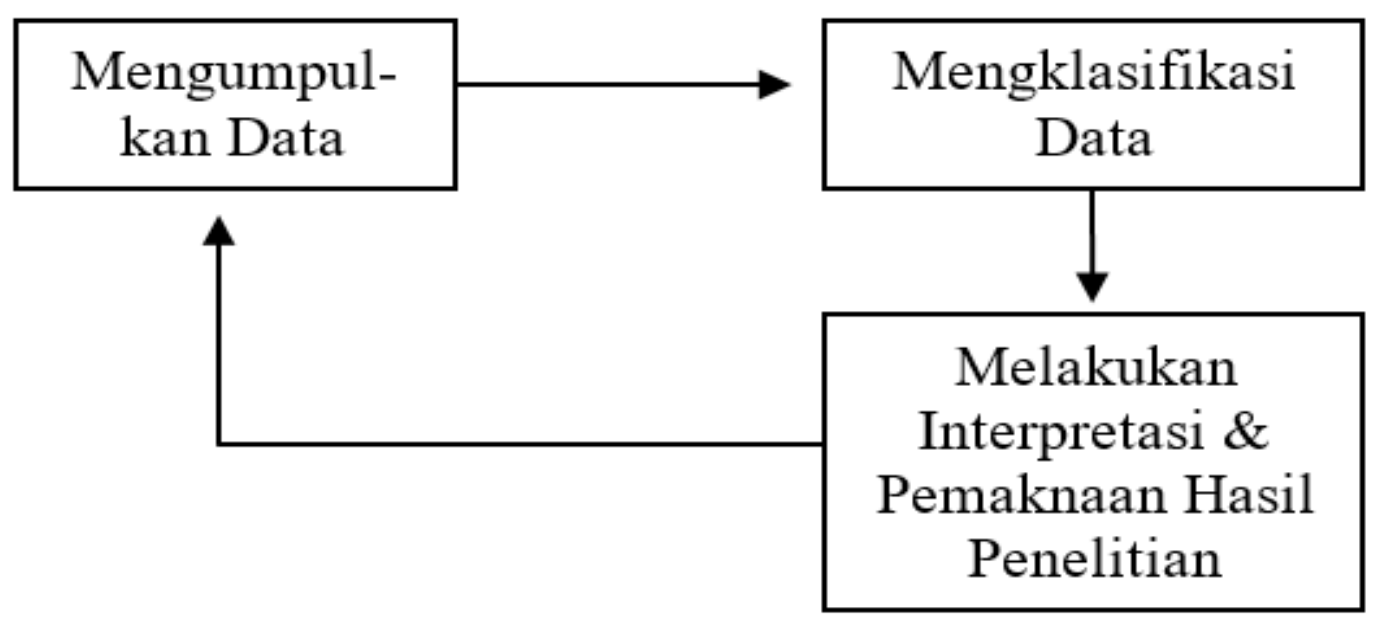

Sumber: Ibrahim, 2016

Gambar 1 Alur Kerja Analisis

perkuliahan di kelas. Sementara wawancara tak langsung melalui lembar korespondensi digunakan untuk menghimpun data dalam bentuk pernyataan atau jawaban tertulis dari para mahasiswa (subjek penelitian), terutama terkait dengan proses pemaknaan pesan yang mindfulness berdasarkan konsep AUM.

Berikutnya, pengumpulan data untuk penelitian ini juga dilakukan melalui sebuah forum diskusi terfokus (focus group discussion). FGD ini dilakukan dalam dua fungsi; pertama, sebagai bentuk pendalaman dan penambahan data-data yang diperlukan dalam penelitian, dengan cara melakukan dialog dan tanya jawab (sharing) mengenai pengalaman komunikasi antarbudaya. Kedua, sebagai sarana melakukan konfirmasi dan memastikan keabsahan data yang diberikan melalui lembar jawaban korespondensi yang telah diberikan jauh hari sebelum FGD dilaksanakan. Melalui serangkaian kegiatan FGD ini peneliti dapat memastikan mengenai data dan ke-akuratannya, sehingga memudahkan bagi proses pemahaman hingga menafsirkan data hasil penelitian.

Kemudian data-data tersebut dianalisis menggunakan teknik analisis pesan komunikasi yang terdiri dari tahapan pengumpulan data, klasifikasi data serta interpretasi dan pemaknaan hasil penelitian. Jika digambarkan dalam bentuk diagram, langkah analisis yang digunakan dapat dilihat pada gambar 1 .

Berdasarkan langkah kerja tersebut, analisis data dalam penelitian tidak berjalan satu arah atau satu rentetan kerja saja. Akan tetapi langkah kerja analisisnya dilakukan secara siklikal (bersiklus), dimana data dikumpulkan, kemudian langsung dilakukan klasifikasi sesuai fokus dan sub fokus penelitian, untuk selanjutnya diberikan interpretasi dan pemaknaannya. Begitulah analisis ini dilakukan secara terusmenerus dan berulang-ulang sampai semua data terkumpulkan, dan pertanyaan penelitian (sebagaimana rumusan fokus dan tujuan penelitian) dapat dijawab dengan baik melalui proses analisis yang cermat dan didukung oleh data yang memadai.

Dengan proses analisis inilah peneliti dapat menjawab pertanyaan penelitian mengenai "pengelolaan kecemasan (anxeity) dan ketidakpastian (uncertainty) dalam komunikasi mahasiswa, mulai proses komunikasi, proses pemaknaan pesan, pengelolaan kecemasan dan ketidak-pastian, hingga proses pemaknaan pesan yang mindfullnes antarbudaya pada mahasiswa IAIN Pontianak.

\section{HASIL DAN PEMBAHASAN}

Proses komunikasi antarbudaya. Sebagaimana pengertian yang disampaikan DeVito, komunikasi antarbudaya sesungguhnya adalah satu bentuk interaksi dan komunikasi diantara partisipan yang berasal dari latar belakang kebudayaan yang saling berbeda (Ibrahim, 2019). Kompleksitas budaya dalam komunikasi, menunjukkan pemahaman 
terhadap budaya dalam komunikasi itu penting, dan karenanya ada banyak pendekatan yang bisa digunakan dalam memahami budaya dalam studi komunikasi antarbudaya (Gudykunst, Toomy, Stella \& Nishida, 1996).

Observasi lapangan melalui proses tatap muka perkuliahan mendapati bahwa mahasiswa KPI semester lima terdiri dari beragam latar belakang kebudayaan yang saling berbeda. Dari sisi etnik misalnya, ada Madura, Melayu, Bugis dan Jawa. Dari sisi asal daerah, ada Sambas, Ketapang, Kayong Utara, Sintang, Nanga Pinoh, Sanggau, dan Kota Pontianak. Dari aspek gender, ada laki-laki dan ada juga perempuan.

Keragaman latar belakang budaya partisipan tersebut menunjukkan bahwa proses komunikasi antarbudaya telah berlangsung dalam interaksi perkuliahan di kelas. Dengan demikian, kemungkinan adanya situasi baru dan asing dalam komunikasi juga ada, sehingga kecemasan dan ketidakpastian dalam komunikasi antarbudaya juga berlaku di ruang kuliah.

Keterbukaan dalam komunikasi antarbudaya diakui oleh mahasiswa sebagai keadaan yang berpengaruh dalam membangun komunikasi yang efektif antarbudaya. Menariknya, sebagian besar mahasiswa memperlihatkan adanya situasi cemas (kecemasan) dan ketidakpastian dalam interaksi awal perkuliahan, terutama oleh faktor situasi yang baru, dengan orang-orang baru dan belum dikenal. Kondisi ini diakui pernah dialami oleh beberapa beberapa mahasiswa dalam bentuk suasana hati yang cemas, grogi, takut salah, tidak percaya diri, bahkan berkeringat dingin ketika akan bicara (Zf, wawancara FGD)

Perasaan yang sama juga diakui oleh mahasiswa yang lain sebagai perasaan grogi, malu, saya merasa takut dan tegang. Akibatnya terkadang tidak bisa menjawab dengan baik setiap pertanyaan yang dosen berikan ( $R n$, wawancara FGD).

Meskipun pada akhirnya mereka mengakui bahwa seiring perjalanan waktu perkuliahan dan interaksi antar mereka, perasaan cemas (kecemasan) dan ketidakpastian tersebut perlahan makin berkurang bersamaan dengan intensitas komunikasi yang terus dilakukan, sebagaimana diakui oleh Ds;

"saya merasa canggung dan malu jika berhadapan dengan orang-orang yang saya anggap memiliki status yang lebih tinggi, lebih dibanding saya. Tapi kalau sudah kenal, tidak lagi terlalu cemas rasanya. Jika dalam suasana hati yang malu dan canggung, ya..saya merasa takut, takut salah gitu. Tapi kalau sudah lama, sudah kenal tidak lagi. Karena itu terkadang saya bisa berkomunikasi dengan nyaman dan maksimal, dan terkadang tidak, jika dalam suasana cemas, canggung dan takut" (Wawancara FGD)

Dengan demikian jelas bahwa dalam proses komunikasi antarbudaya, terutama untuk suasana yang baru dan asing, kebanyakan mahasiswa mengalami situasi yang cemas (anxiety) dan tidak pasti (uncertainty), baik dalam bentuk rasa kekhawatiran, keraguan, grogi, canggung, hingga perasaan serba salah dan semacamnya. Kondisi seperti ini tentu saja sangat berpengaruh dalam proses komunikasi antarbudaya yang dilangsungkan.

Pemaknaan pesan adalah substansi dari sebuah proses komunikasi. Artinya, pesan dan pemaknaan pesanlah yang paling utama dalam setiap proses komunikasi. Dalam konteks komunikasi antarbudaya, pesan disampaikan dalam simbol dan lambang yang mungkin saling berbeda, dengan makna dan konteks yang berbeda pula. Karena itu aspek budaya bahasa (linguistik community) menjadi penting untuk dipahami dalam proses pemaknaan pesan komunikasi (Ahmad, 2011).

Proses pemaknaan pesan dalam komunikasi antarbudaya mahasiswa di kelas, bukan saja dipengaruhi oleh situasi awal yang mencemaskan dan menimbulkan ketidakpastian, tapi juga latar belakang partisipan yang saling berbeda yang secara bersama-sama membawa pada perasaan kecemasan dan ketidakpastian dalam berkomunikasi. Karena itu, perbedaan budaya, simbol dan lambang yang digunakan dalam berkomunikasi, serta situasi interaksi awal yang cemas dan ketidak-pastian sangat berpengaruh pada proses pemaknaan pesan yang dipertukarkan antar mahasiswa yang berbeda latar belakang budaya.

Pertama, komunikasi yang sebagian besarnya dilalui dengan rasa cemas dan tidak pasti di awal-awal interaksi akan berakibat pada kesalahan dan ketidak-akuratan dalam menafsirkan pesan yang disampaikan. Ada semacam keragu-raguan dalam memahami 
pesan yang sebenarnya yang diinginkan dari proses komunikasi dalam situasi cemas dan tidak-pasti, sebagaimana pernyataan informan yang menunjukkan pada katagori selalu:

\section{Pernyataan 1:}

Ketika pertama kali bertemu dengan orang yang belum saya kenal, saya sangat berhati-hati dalam berkomunikasi (Kh, Hr, Pr, St, As, Ps, $\mathrm{Fz}, \mathrm{dll})$

\section{Pernyataan 2:}

Terkadang saya ragu dalam memberikan jawaban dari pertanyaan orang yang baru saya kenal (Hr, Da)

\section{Pernyataan 3:}

Saya merasa malu dengan orang yang belum saya kenal, karena itu saya selalu berupaya menjaga jarak dalam berkomunikasi (Kh, Ai, Ds, An, dll)

Dari data tersebut dapat dipahami bahwa adanya keraguan-raguan dalam proses komunikasi yang berlangsung antarbudaya pada mahasiswa, baik dalam proses maupun pemaknaannya, dengan katagori kecemasan (anxiety) dan ketidak-pastian (uncertainty) dalam tahapan tinggi (selalu). Dengan kondisi demikian, tentu saja akan memberikan pengaruh yang besar dalam proses komunikasi antarbudaya, dan pemaknaan pesan yang tepat dan efektif antarbudaya pada sebagian besar mahasiswa.

Tidak jauh dengan kondisi di atas, data lapangan juga menunjukkan bahwa proses dan pemaknaan pesan komunikasi dalam situasi cemas (anxiety) dan ketidak-pastian (uncertainty) juga dialami oleh beberapa informan yang lainnya, meskipun dalam level yang tidak terlalu sering (kadang-kadang). Sebagaimana terlihat dalam pernyataan informan berikut:

\section{Pernyataan 1:}

Ketika pertama kali bertemu dengan orang yang belum saya kenal, saya sangat berhati-hati dalam berkomunikasi (Ns, Tr, Rz, Da, Sh, Am, Im)

Pernyataan 2:

Terkadang saya ragu dalam memberikan jawaban dari pertanyaan orang yang baru saya kenal (Kh, Rn, Tr, Rz, Pt, St, Ag, dll)

Kedua, adanya kecendrungan memaknai pesan dalam komunikasi dengan mencari kesamaan konteks dan teks. Artinya, sebuah simbol yang digunakan dalam berkomunikasi akan ditafsirkan sebagaimana pesan dalam latar belakang sosial dan budaya partisipan yang berbeda (Sihabudin, 2013). Karenanya, perbedaan budaya dan latar belakang partisipan sangat memungkinkan terjadinya perbedaan dalam menangkap makna dari sebuah simbol komunikasi yang dilakukan, sebagaimana dalam pernyataan informan berikut:

Pernyataan 1:

Dalam berkomunikasi saya selalu berusaha menggunakan kalimat/bahasa yang sesuai dengan lawan bicara saya (Rn, Pt, St, Fz, Zl, Ms, Fd, dll)

\section{Pernyataan 2:}

Ketika orang yang baru saya kenal menyapa atau menanyakan sesuatu, biasanya saya berpikir dulu sejenak sebelum memberikan jawaban (Kh, Pt, Ag, Sh, Ps, Fm, dll)

Data di atas memberikan pemahaman bahwa adanya kecendrungan melakukan komunikasi dan proses pemaknaannya dengan menjadikan (perbedaan) latar belakang partisipan sebagai indikator utamanya. Terutama dalam konteks perasaan diri yang cemas dan tidak pasti karena situasi komunikasi yang baru. Proses dan pemaknaan komunikasi dalam kondisi seperti ini diakui oleh sebagian informan sebagai sesuatu yang sering terjadi dalam komunikasi antarbudaya yang mereka lakukan.

Situasi yang hampir serupa juga diakui oleh beberapa informan yang lain, dengan level yang cukup sering terjadi (kadang-kadang), Sebagaimana terlihat dalam pernyataan informan berikut:

\section{Pernyataan 1:}

Dalam berkomunikasi saya selalu berusaha menggunakan kalimat/bahasa yang sesuai dengan lawan bicara saya (Vi, Ak, Ds, Hp, Na, Mh, dll)

\section{Pernyataan 2:}

Ketika orang yang baru saya kenal menyapa atau menanyakan sesuatu, biasanya saya berpikir dulu sejenak sebelum memberikan jawaban (Vi, Ls, Fd, Ds, Na, Ns, dll)

Ketiga, kecemasan dan ketidak-pastian dalam proses komunikasi dan interaksi awal, 
dengan kemungkinan kekeliruan dalam menafsirkan pesan dari simbol-simbol antarbudayayang saling berbeda, secaraperlahan mengalami perbaikan dan perubahan ke arah positif, seiring dengan intensitas komunikasi dan interaksi antar partisipan. Perlahan namun pasti, para mahasiswa mengakui bahwa semakin lama interaksi dibangun diantara mereka menjadikan mereka saling mengerti dan memahami satu sama lain. Dari sisi proses, perasaan cemas dan ketidak-pastian juga semakin menghilang dalam komunikasi antara mereka.

Berikut pernyataan seorang informan ketika memberikan tanggapan saat wawancara FGD dilakukan.

"saya merasa canggung dan malu jika berhadapan dengan orang-orang yang saya anggap memiliki status yang lebih tinggi dibanding saya. Tapi kalau sudah kenal, tidak lagi terlalu cemas rasanya. Jika dalam suasana hati yang malu dan canggung, ya..saya merasa takut, takut salah gitu. Tapi kalau sudah lama, sudah kenal tidak lagi. Karena itu terkadang saya bisa berkomunikasi dengan nyaman dan maksimal,..."(Ds)

Berbagai perasaan kecemasan (anxiety) seperti malu, canggung, takut salah, grogi dan sebagainya bukan saja dialami oleh setiap mahasiswa dalam situasi komunikasi yang baru (sebagaimana diakui oleh banyak informan), melainkan juga membawa pada suasana hati yang tidak pasti (ketidak-pastian/uncertainty). Kondisi ini juga diakui sebagai sangat berpengaruh dalam proses pemaknaan pesan dalam komunikasi antarbudaya yang mereka lakukan.

Kecemasan (anxiety) adalah situasi psikologi dimana seseorang merasakan ketidak-nyamanan atau ketidak-tenangan yang disebabkan oleh beberapa faktor, terutama faktor eksternal berupa situasi dan kondisi yang dirasa asing dan baru. Kecemasan biasanya juga wujud dalam bentuk perasaan was-was, khawatir, dan berbagai perasaan dan pikiran yang tidak menentu. Secara fisik, kecemasan dapat dikenali dengan penampilan yang tidak wajar (salah tingkah), grogi, canggung, dan bahkan gemetaran. Kecemasan juga dapat dilihat dalam cara bicara yang gugup, kurang teratur dan terbata-bata.

Lebih lanjut, kecemasan yang tinggi juga akan berpengaruh pada sikap atau prilaku yang tidak pasti. Kecemasan dan ketidak-pastian memunculkan perilaku dan sikap hidup yang ragu-ragu dan tidak konsisten. Akibatnya adalah seringkali pengambilan keputusan sikap atau prilaku tidak dengan pertimbangan yang baik dan tepat. Jika pun harus dengan pertimbangan, itupun berlangsung dalam proses yang tidak alamiah, tapi dramatisasi.

Partisipan yang mengalami persoalan psikologi yang cemas (kecemasan) dan ketidakpastian juga akan mengalami persoalan dalam komunikasi, baik ketika menyampaikan pesan, penggunaan simbol, hingga proses pemaknaan simbol dan pesan yang dibawanya. Intinya, diperlukan kemampuan pengelolaan yang baik dan efektif atas perasaan psikologi kecemasan dan ketidakpastian dalam berkomunikasi. Sebab, kecemasan dan ketidakpastian hampir dialami oleh setiap orang dalam situasi kumunikasi yang baru dan asing baginya.

Terkait dengan pengelolaan kesemasan dan ketidakpastian dalam komunikasi mahasiswa, kajian lapangan mendapati dua sikap yang diambil oleh mahasiswa dalam menghadapi persoalan kecemasan (anxiety) dan ketidakpastian (uncertainty) dalam komunikasi antarbudaya;

Berupasikappenerimaandanadaptasidalam komunikasi. Sikap ini melahirkan setidaknya tiga bentuk pengelolaan kecemasan (anxiety) dan ketidak-pastian (uncertainty), yakni: 1) adanya upaya untuk terus meningkatkan proses interaksi dan komunikasi menjadi lebih intens, akrab dan pamiliar. Dengan cara ini, situasi baru dan asing akan berubah secara perlahan dan pasti menjadi situasi yang akrab dan pamiliar. Dengan demikian perasaan asing dan tidak pamiliar yang menjadi faktor penyebab kecemasan dan ketidak-pastian berganti menjadi keakraban dan situasi yang bersahabat. Sebagaimana diakui oleh salah seorang narasumber ketika ditanya mengenai apa yang akan dilakukannya ketika merasa ragu dan bingung dalam suatu peristiwa komunikasi antarbudaya yang baru (asing):

"saya akan diam, namun saya akan berpikir agar jawaban dari komunikasi saya bisa tepat. Tetapi saya juga akan bertanya teman yang saya akrabkan untuk menanyakan pendapatnya" (Tr./LK/B5).

Pengakuan tersebut sangat sesuai dengan pernyataannya ketika ditanya mengenai sikap 
Tabel 1 Komunikasi dalam Kecemasan dan Cara Mengatasinya

\begin{tabular}{|c|c|c|c|}
\hline No & $\begin{array}{l}\text { Sikap berkomunikasi dalam bingung/ } \\
\text { grogi }\end{array}$ & $\begin{array}{c}\text { Cara dalam mengatasi kebingungan/ } \\
\text { grogi }\end{array}$ & Kode Inf \\
\hline 1 & $\begin{array}{l}\text { Bertanya kepada orang yang lebih } \\
\text { tau }\end{array}$ & $\begin{array}{l}\text { Dengan percaya diri dan berpikiran } \\
\text { pisitif }\end{array}$ & $\mathrm{Rz}$ \\
\hline 2 & $\begin{array}{l}\text { Mensamarkan keraguan dan } \\
\text { menganggap biasa saja }\end{array}$ & $\begin{array}{l}\text { Menganggap orang yang didepan anda } \\
\text { itu tidak ada }\end{array}$ & $\mathrm{Da}$ \\
\hline 3 & Bertanya kepada teman dulu & $\begin{array}{l}\text { Melakukan tarik napas dan hembuskan, } \\
\text { dan banyak bicara }\end{array}$ & Pt. \\
\hline 4 & $\begin{array}{l}\text { Menenangkan diri dulu dan berusaha } \\
\text { untuk berkenalan }\end{array}$ & $\begin{array}{l}\text { Tenangkan pikiran dulu dan berusaha } \\
\text { berbicara seakan sama orang yang } \\
\text { sudah kenal lama }\end{array}$ & St. \\
\hline
\end{tabular}

Sumber: Lembar Korespondensi B, 2016

yang akan dilakukannya untuk mengatasi perasaan grogi/ salah tingkah dalam komunikasi:

"saya akan melawan perasaan grogi itu dan berbicara di dalam hati bahwa tidak ada perbedaan, agar saya tidak salah tingkah saat berkomunikasi dengan orang yang lebih dari saya" (Tr./LK/B6)

Pendapat yang hampir serupa dapat dilihat dalam beberapa pernyataan, sebagaimana dalam tabel 1 .

2) adanya upaya untuk saling memahami beberapa aspek kebudayaan yang menjadi faktor munculnya kecemasan dan ketidakpastian dalam komunikasi antarbudaya, antaranya adalah pemahaman akan simbolsimbol komunikasi yang saling berbeda diantara partisipan yang berasal dari budaya etnik / asal daerah yang juga berbeda. Upaya ini dilakukan dengan cara menghindari penilaian tunggal terhadap simbol komunikasi yang digunakan hanya dengan makna kebudayaan sendiri, melainkan mencari konsep dan pemaknaan berdasarkan kebudayaan lawan bicara. Lebih jelas mengenai sikap yang harus dilakukan ketika bertemu dengan orang baru dengan perilaku yang juga aneh dan tidak lazim menurut kebiasaan sendiri, berikut pernyataan mahasiswa:

Pernyataan 1:

Saya mencoba mendekati orang itu agar saya bisa mengenalinya (St/LK.B2).

Pernyataan 2:
Saya akan berprilaku memaklumi serta saling memahami (Am/LK.B2).

Pernyataan 3:

Saya akan lebih berhati-hati dan berpikir positif (Fz/LK.B2).

3) pengelolaan kecemasan dan ketidakpastian juga dilakukan dengan cara mengatur proses komunikasi dengan baik dan tepat. Artinya, ada managemen waktu mengenai proses komunikasi dan interaksi, kapan harus memulai, menyiapkan diri memulai komunikasi, menentukan jarak dan pemilihan teman, dan sebagainya. Lebih jelasnya mengenai sikap terhadap ketidak-laziman perilaku dalam komunikasi antarmahasiswa, berikut pernyataannya:

Pernyataan 1:

Sikap yang harus saya lakukan terhadap orang tersebut, saya akan menegur dan memberi tahu kepadanya bahwa prilakunya itu tidak boleh dilakukan (Ms/LK.B2).

Pernyataan 2:

Saya berusaha untuk mengetahui penyebab prilakunya, karena bisa saja ketidak-laziman yang dilakukannya menurut saya itu merupakan hal yang lazim baginya, karena faktor bedanya budaya kita (Vi/LK. B2).

\section{Peryataan 3:}

Saya hanya melihat dan berkata di dalam hati saja. Jika negatif prilaku mereka saya akan berkata dengan lembut untuk mengingatkannya 
Tabel 2 Pengelolaan Sikap terhadap Perbedaan (menghindari)

\begin{tabular}{lll}
\hline \multicolumn{1}{c}{ Tema Sikap } & $\begin{array}{l}\text { Sikap } \begin{array}{c}\text { Terhadap } \\
\text { Perbedaan }\end{array} \\
\text { Inf. }\end{array}$ \\
\hline $\begin{array}{l}\text { Sikap ketika } \\
\text { melihat } \\
\text { orang-orang } \\
\text { baru dan } \\
\text { prilaku aneh/ } \\
\text { tidak lazim } \\
\text { menurut } \\
\text { kebiasaan } \\
\text { anda }\end{array}$ & & \\
& & \\
& $\begin{array}{l}\text { Merasa cangetah diri } \\
\text { dan menghindar }\end{array}$ & \\
& $\begin{array}{l}\text { Lebih memilih } \\
\text { menghindar }\end{array}$ & $\mathrm{Im}$ \\
\hline
\end{tabular}

Sumber: Lembar Korespondensi B.2, 2016

(Ak/LK.B2).

b). Berupa sikap penolakan dengan menghindari kontak komunikasinya.

Sikap ini melahirkan dua bentuk pengelolaan kecemasan (anxiety) dan ketidakpastian (uncertainty) dalam komunikasi antarbudaya mahasiswa, yakni menghindari sebisa mungkin kontak (interaksi) komunikasi dalam suasana baru antarbudaya. kondisi ini diakui oleh beberapa informan lapangan, sebagaimana dapat dipahami dari pernyataan pada tabel 2 .

Mengabaikan setiap perbedaan yang ada dalam proses komunikasi antarbudaya yang dilakukan, termasuk perasaan cemas, ragu, grogi, salah tingkah dan sebagainya. Bahkan beberapa upaya untuk mengabaikan perbedaan latar belakang partisipan dan bentuk-bentuk komunikasi yang berlangsung dalam suasana tersebut. Hal ini terlihat dalam beberapa pernyataan informan yang ditampilkan di dalam tabel 3.

Kondisi di atas mengingatkan kita pada kajian Winda Primasari mengenai pengelolaan kecemasan dan ketidakpastian pada mahasiswa perantau di UNISMA Bekasi melalui strategy Interaktif dan pertukaran afektif dalam bentuk komitmen pertemanan dan persahabatan (Primasari, 2014).
Tabel 3 Pengelolaan Sikap terhadap Perbedaan (mengabaikan)

\begin{tabular}{lll}
\hline Tema Sikap & $\begin{array}{l}\text { Sikap Terhadap } \\
\text { Perbedaan }\end{array}$ & Inf. \\
\hline $\begin{array}{l}\text { Sikap ketika } \\
\text { melihat } \\
\text { orang-orang } \\
\text { baru dan } \\
\text { prilaku aneh/ } \\
\text { tidak lazim } \\
\text { menurut } \\
\text { kebiasaan } \\
\text { anda }\end{array}$ & & \\
& & \\
& $\begin{array}{l}\text { Saja memilih diam } \\
\text { membiarkan \& }\end{array}$ & \\
& $\begin{array}{l}\text { Tidak } \\
\text { memperdulikannya } \\
\text { Memperhatikan } \\
\text { dan diam saja }\end{array}$ & $\mathrm{Fd}$ \\
& $\begin{array}{l}\text { Biasa saja dan } \\
\text { tidak memikirkan }\end{array}$ & $\mathrm{Nd}$ \\
\hline
\end{tabular}

Sumber: Lembar Korespondensi B.2, 2016

Singkatnya, apapun sikap yang diambil terkait dengan pengelolaan kecemasan (anxiety) dan ketidakpastian (uncertainty) dalam komunikasi antarbudaya, pastinya pengelolaan yang baik akan persoalan tersebut penting dilakukan guna mewujudkan proses komunikasi yang baik dan efektif antarbudaya. Dua sisi penghindaran ketidak-pastian (uncertainty avoidance) yang mungkin dilakukan, yakni toleransi budaya, dan atau intoleransi ketidakpastian (Marta \& Rieuwpassa, 2018). Sebab itu menurut Gudykunts, pengelolaan sikap diri sebagai orang asing dalam suasana komunikasi yangbaruantarbudayasemestinyamenjembatani jarak dalam berkomunikasi, sehingga komunikasi menjadi efektif. (Sukmono, Filosa \& Junaedi, 2014). Begitulah asumsi dari teori pengelolaan kecemasan dan ketidakpastian (anxiety-uncertainty management theory).

Proses Pemaknaan Pesan yang Mindfulness. Proses pemaknaan pesan adalah menyangkut upaya-upaya dan tahapan prosedural dalam memahami, memaknai dan menangkap pesan yang disampaikan dalam suatu peristiwa komunikasi antarbudaya. Sementara pesan yang mindfulness dapat dipahami sebagai 
pesan-pesan komunikasi yang dilekatkan secara sadar dengan perbedaan yang ada antar partisipan. Artinya, pesan yang mindfulness adalah pemahaman pesan dari suatu peristiwa komunikasi yang dijalankan secara sadar dan diakui sebagai berbeda antarbudaya.

Proses pemaknaan pesan yang mindfulness antarbudaya adalah tahapan atau upaya pemaknaan pesan-pesan komunikasi dalam sebuah kesadaran bahwa adanya perbedaan latar belakang partisipan. Seorang partisipan dalam peristiwa komunikasi antarbudaya dapat memahami dan memaknai pesan yang dipertukarkan bukan karena kesamaan latar belakangnya, melainkan karena kesadaran akan perbedaan latar belakang para partisipannya. Dalam proses pemaknaan pesan seperti ini biasanya ada kecendrungan memaknai setiap simbol yang tampak dalam proses komunikasi dengan tafsiran budaya masing-masing, dan disadari sebagai makna sendiri atau kelompok sendiri yang bisa saja berbeda dengan makna orang lain atau dari kelompok budaya lain yang berbeda. Jika pun ada upaya untuk menemukan makna yang "benar" dan dapat diterima oleh partisipan komunikasi dari budaya yang berbeda, itupun tidak bisa lepas dari pengaruh budaya sendiri atau kelompok diri yang menggunakan dan memaknai simbol yang digunakan.

Data kajian lapangan mendapati beberapa variasi jawaban yang diberikan oleh para mahasiswa ketika diminta memaknai istilah

\section{persabahatan dan kesuksesan.}

Dari keseluruhan jumlah mahasiswa yang diberikan pertanyaan, didapati variasi yang sangat signifikan dalam pemberian makna istilah persahabatan. Pada makna pertama, istilah persahabatan didefinisi dalam 13 variasi jawaban. Sedangkan makna kedua, didapati sebanyak 21 variasi jawabannya. Data tersebut menunjukkan adanya varian yang signifikan dalam pemberian makna komunikasi antarbudaya pada mahasiswa.

Begitupun ketika mereka diminta untuk memberikan makna tentang kesuksesan. Data lapangan menunjukkan adanya perbedaan signifikan dalam pemberian makna pertama dan makna kedua. Jika untuk istilah Persahabatan menunjukkan makna pertama dan makna kedua dalam perbandingan variannya $13-21$, maka untuk istilah Kesuksesan menunjukkan adanya keseimbangan varian makna yang diberikan, yakni masing-masing 15 makna pertama dan makna kedua.

Terlepas dari perbedaan varian makna pertama dan kedua untuk masing-masing istilah yang diberikan, kondisi ini menunjukkan tingginya varian pemaknaan yang diberikan oleh informan dalam konteks komunikasi antarbudaya. Jika dilihat dari besaran jumlah informan, maka varian jawaban yang diberikan pun hampir sama besar variannya dengan jumlah informan yang saling berbeda dalam satu konteks komunikasi antarbudaya.

Dengan demikian dapat dipahami bahwa dalam memaknai pesan yang mindfulness, selalunya simbol-simbol komunikasi yang digunakan-ditafsirkan berdasarkan pada latar belakang budaya masing-masing (sebagai makna pertama). Baru selanjutnya ditafsirkan dengan makna dalam budaya lawan bicara (sebagai makna kedua dan seterusnya). Kompromi antara makna pertama dengan makna kedua itulah yang selanjutnya menjadi proses pemaknaan pesan berikutnya dalam komunikasi antarbudaya yang mindfulness.

Proses pemaknaan pesan yang mindfulness pada prinsipnya adalah satu upaya mewujudkan komunikasi yang efektif antarbudaya. Mengacu pada konsep Gudykunst (pelopor Teori AUM), menyebutkan komunikasi efektif adalah merujuk pada proses untuk mengurangi kesalahpahaman (misunderstanding), atau dalam istilah lain dikenal dengan akurasi (accuracy), kejituan (fidelity), atau pemahaman (understanding) (Sukmono, Filosa \& Junaedi, 2014).

Dalam konteks komunikasi antarmahasiswa dalam suasana baru antarbudaya, proses pemaknaan pesan yang mindfulness mestinya juga dilakukan dalam upaya mewujudkan efektifitas hubungan berupa kemampuan untuk saling memprediksi dan menjelaskan prilaku orang lain. Itulah yang oleh Gudykunst disebut sebagai kemampuan menjelaskan komunikasi tatap muka (face to face) yang efektif(Sukmono \& Junaedi, 2014).

Kondisi tersebut mengingatkan kita bahwa, faktor budaya dan perbedaan nilai di dalamnya menjadi dasar bagi setiap orang dalam memberikan makna terhadap sebuah simbol komunikasi sebagaimana kajian Ahmad terhadap bahasa dan nilai budaya Melayu Malaysia dalam membangun kecerdasan komunikasi antarbudaya (Ahmad, Noh, Mohamad, Mohd, Salman \& Pawentah, 2015). 


\section{SIMPULAN}

Secara umum, hasil kajian ini menghasilkan kesimpulan bahwa proses komunikasi dan pemaknaan pesan yang mindfulness berdasarkan konsep pengelolaan kecemasan dan ketidakpastian antarbudaya berlaku dalam pengalaman komunikasi mahasiswa IAIN Pontianak. Dimana umumnya mahasiswa juga mengalami situasi komunikasi yang tidak nyaman, grogi, canggung dan cemas, terutama dalam situasi yang baru (asing). Akibatnya memunculkan sikap serba tidak pasti dalam berkomunikasi. Seiring perjalanan waktu, proses komunikasi dan pemaknaan pesan perlahanlahan mengalami perubahan dari situasi cemas (anxiety) dan tidakpasti (uncertainty) menuju komunikasi yang penuh dengan kesadaran diri (mindfulness) antarbudaya.

Secaraspesifik, hasilpenelitianinimendapati bahwa; Proses komunikasi berlangsung dalam berbagai latar belakang kebudayaan yang saling berbeda antar mahasiswa, baik etnik maupun asal daerah, terutama dalam interaksi perkuliahan. Situasi baru (asing) juga dirasakan oleh mahasiswa sebagai faktor pemicu timbulnya perasaan cemas (kecemasan) dan serba salah (ketidakpastian) dalam komunikasi.

Proses pemaknaan pesan dalam komunikasi pada mahasiswa yang berbeda latar belakang kebudayaan pada satu sisi, dan adanya perasaan cemas (kecemasan) dan serba salah (ketidakpastian) di sisi lain, berlangsung dalam tiga tahap; a) komunikasi yang sebagian besarnya dilalui dengan rasa kecemasan dan ketidakpastian di awal-awal interaksi berakibat pada kesalahan dan ketidak-akuratan dalam menafsirkan pesan yang disampaikan; b) adanya kecendrungan memaknai pesan dalam komunikasi dengan mencari kesamaan konteks dan teks; c) kecemasan dan ketidakpastian dalam proses komunikasi dan interaksi awal, dengan kemungkinan kekeliruan dalam menafsirkan pesan dari simbol-simbol antarbudaya, secara perlahan mengalami perbaikan dan perubahan ke arah positif, seiring dengan intensitas komunikasi dan interaksi antar partisipan. Dari sisi proses, perasaan cemas dan ketidakpastian juga semakin menghilang dalam komunikasi antara mereka.

Pengelolaan kecemasan dan ketidakpastian dalam komunikasi pada mahasiswa dilakukan dalam bentuk; pertama, sikap penerimaan dan adaptasi dalam komunikasi yang meliputi (a) adanya upaya untuk terus meningkatkan proses interaksi dan komunikasi menjadi lebih intens, akrab dan pamiliar, (b) adanya upaya untuk saling memahami beberapa aspek kebudayaan yang menjadi faktor munculnya kecemasan dan ketidakpastian dalam komunikasi antarbudaya, (c) pengelolaan kecemasan dan ketidakpastian juga dilakukan dengan cara mengatur proses komunikasi dengan baik dan tepat;

Kedua, sikap penolakan dengan menghindari kontak komunikasinya, yakni (a) menghindari sebisa mungkin kontak (interaksi) komunikasi dalam suasana baru antarbudaya, (b) mengabaikan setiap perbedaan dalam proses komunikasi antarbudaya yang dilakukan, termasuk perasaan cemas, ragu, grogi, salah tingkah dan sebagainya.

Proses pemaknaan pesan yang mindfulness dalam komunikasi mahasiswa berlangsung dalam berbagai varian, bahkan sangat beragam. Kondisi ini diduga dipengaruhi oleh perbedaan latar belakang yang ada di antara mereka, baik etnik, maupun asal daerah. Sebagian besar mahasiswa memberikan makna pesan berdasarkan latar belakang pengetahuan dan pengalaman masing-masing sebagai makna pertama, dan pengalaman budaya lawan bicara sebagai makna kedua dan seterusnya. Perjalanan waktu dalam komunikasi dan interaksi di kelas membawa mereka pada bentuk pemaknaan pesan yang mindfulness, yang lebih kompromistis dan lebih efektif antarbudaya.

Hasil kajian ini menegaskan bahwa adanya potensi kecemasan (Anxiety) dan ketidakpastian (Uncertainty) dalam komunikasi mahasiswa IAIN Pontianak, terutama interaksi awal di ruang kelas. Karena itu, diperlukan kemampuan pengelolaan diri dan komunikasi yang baik dari setiap partisipan komunikasi antarbudaya di kampus sebagaimana konsep AUM (AnxietyUncertainty Management) dari Gudykunst. Dengan demikian, proses pemaknaan pesan yang mindfulness, kompromistis dan efektif antarbudaya di kalangan mahasiswa IAIN Pontianak mungkin didapatkan.

\section{DAFTAR PUSTAKA}

Ahmad et al., (2015). Eksplorasi adaptasi antarbudaya pelajar Melayu di Australia dan United Kingdom. Jurnal KomunikasiMalaysian Journal of Communication, 
2(31), 389-403.

Ahmad, C. M. (2011). Notes on ethno pragmatics as a device for intercultural communication intelegensia (ICQ. International Journal of Philosopy of Culture and Axiology, 8(2), 63-72.

Berger, C. R., Roloff, M. E., \& RoskosEweldsen, D. R. (2014). Handbook ilmu komunikasi. Bandung: Nusamedia.

Dalib, S., Harun, M., Yusof, N. (2017). Identity dan intercultural competence: probing student experiences in Malaysian Campuses. Malaysian Journal of Communication, 33(3), 107-124.

Diana, A. \& Lukman, E. (2018). Pengelolaan kecemasan dan ketidakpastian dalam komunikasi antarbudaya antara auditor dan auditee. Jurnal Komunikasi Indonesia, 7(1), 99-108.

Edelmann, R. J. (1992). Anxiety theory: research and intervention in clinical and health psychological. Chichester.

Gudykunst, W. B., Toomy, S, T., Nishida, T. (1996). Communication in personal relationships across cultures. USA: SAGE Publications.

Handini, A. (2014). Cemas, masalah atau solusi. Pontianak: STAIN Press.

Ibrahim. (2017). Komunikasi antarbudaya. Bandung (Kedua). Bandung: Alfabeta.

Ibrahim. (2019). Cultural context in intercultural communication: case of students at IAIN Pontianak, Indonesia. Jurnal Komunikasi: Malaysian Journal of Communication, 35(2), 227-246.

Kelly, K. (2014). Coding miscommunication: a methode for capuring the vagaries of language. St. Edward University.

Littlejohn, S. W \& Foss, K. A. (2009). Teori komunikasi (9th ed.). Jakarta: Salemba Humanika.
Marta, R. F. \& Rieuwpassa, J. S. (2018). Identifikasi nilai kemajemukan Indonesia sebagai identitas bangsa dalam iklan mixagrif versi keragaman budaya. Jurnal Kajian Komunikasi, 6(1), 37-50.

Oluga, S. O. (2010). Ambiguity in human communication: causes, consequences and resolution. Malaysian Journal of Communication, 26, 37-46.

Primasari, W. (2014). Pengelolaan kecemasan dan ketidakpastian diri dalam berkomunikasi. Jurnal Ilmu Komunikasi, 12(1), 26-36.

Putri, N. E., Hakim, N., \& Yamin, M. (2016). Ecologicall footprint and biocapacity analysis for flooding prevention in south Sumatera. Jurnal Mimbar, 32(1), 58-64.

Raharjo, T. (2004). Mindfulness dalam komunikasi antaretnis. Jurnal Thesis, $\operatorname{III}(2), 97-119$.

Ramaiah, S. (2003). Kecemasan, bagaimana mengatasi penyebabnya. Jakarta: Pustaka Populer Obor.

Saputra, S. J. (2017). Ruang keseharian sebagai refresentasi identitas personal. Jurnal Kajian Komunikasi, 5(1), 81-90.

Sinaulan, R. L. (2016). Komunikasi terapetik dalam perspektif islam. Jurnal Komunikasi Islam, 6(1), 128-157.

Sukmono, F. G., \& Junaedi, F. (2014). Komunikasi multikultur (Kedua). Jogjakarta: Buku Lentera.

Wahyuni, E. (2015). Hubungan self-efficacy dengan keterampilan komunikasi dengan kecemasan berbicara di depan umum. Jurnal Komunikasi Islam, 5(1), 51-82.

Wesmira. (2016). Cara meningatkan kualitas hidup dengan kesadaran diri (mindfulness). psychological consultancy service. Retrieved from www.psychologytoday. com/wesmira.com. 